\title{
RESEARCH GAP DAN MODEL FAKTOR YANG MEMPENGARUHI TINGKAT FERTILITAS: REVIEW LITERATUR
}

\author{
RESEARCH GAP AND MODEL FACTORS AFFECTING FERTILITY LEVEL: \\ A LITERATURE REVIEW \\ Muhamad Jumliadi ${ }^{1}$, Yoyok Hendarso ${ }^{2}$, Nengyanti ${ }^{3}$ \\ ${ }^{1,2,3}$ Program Studi Kependudukan, Universitas Sriwijaya, Sumatera Selatan Indonesia \\ email: jumliadi87@gmail.com
}

Info Artikel: Diterima: 13 Februari $2020 \quad$ Revisi: 20 Mei $2020 \quad$ Disetujui: 15 Juni 2020

\begin{abstract}
ABSTRAK
Latar Belakang: Komponen demografi, kelahiran (fertilitas), kematian (mortalitas) dan migrasi merupakan tri matra kependudukan yang merupakan penentu utama tinggi rendahnya pertumbuhan penduduk. Jumlah penduduk dunia dari tahun ke tahun mengalami peningkatan termasuk juga di Indonesia disebabkan oleh adanya kelahiran (Fertilitas). Tujuan penelitian ini adalah untuk mengindentifikasi faktorfaktor yang berhubungan dengan tingkat fertilitas serta mengidentifikasi research gap guna untuk penelitian dimasa yang akan datang.

Metode: Penelitian ini merupakan studi literatur dengan menelaah 30 jurnal dengan topik dan tema yang sama terkait faktor-faktor yang mempengaruhi tingkat fertilitas.

Hasil: analisis penelitian ini menunjukkan bahwa faktor-faktor yang mempengaruhi fertilitas dari beberapa literatur mengacu pada teori Freedman yaitu faktor tidak langsung terdiri dari: faktor demografis (variabel kontrol); faktor sosial dan ekonomi; faktor mortalitas (kematian anak); faktor norma; faktor lingkungan; dan faktor langsung, terdiri: hubungan seksual (intercourse), konsepsi (conception) dan kehamilan (gestasi). Hasil telaah literatur dari 30 jurnal menunjukkan terdapat research gap yaitu dalam aspek metodologi, dimana banyak penelitian sebelumnya mayoritas menggunakan metode kuantitatif, serta terdapat gap dalam tempat dan objek penelitian dimana mayoritas penelitian-penelitian terdahulu umumnya hanya fokus pada PUS dengan umur 15-49 (pasangan usia subur) dan belum ada penelitian yang membandingkan tingkat fertilitas antar negara.

Kesimpulan: faktor-faktor yang yang mempengaruhi tingkat fertilitas dari beberapa literatur dapat disimpulkan bahwa tinggi rendahnya tingkat fertilitas di suatu daerah atau wilayah adalah hasil dari keputusan individu untuk membatasi kelahiran. Keputusan ini tidak terlepas dari interaksi proses perubahan sosial, budaya, norma, kepercayaan, ekonomi dan pertumbuhannya, urbanisasi dan modernisasi.
\end{abstract} Kata kunci : Tingkat Fertilitas, Literatur Studi

\section{ABSTRACT}

Background: The components of demography, fertility, mortality and migration are the three dimensions of population which are the main determinants of population growth. The world population has increased from year to year, including in Indonesia, it was due to birth (Fertility). The purpose of this study is to identify factors related to fertility rates and identify research gaps for future research.

Method: This research is a literature study by examining 30 journals with the same topics and themes related to factors that affect fertility levels.

Results: the analysis of this study showed that the factors affecting fertility from some of the literature refer to Freedman's theory, namely indirect factors consisting of: demographic factors (control variables); social and economic factors; mortality factor (child mortality); the norm factor; environmental factors; and direct factors, consisting of: sexual intercourse (intercourse), use of contraception (conception), and pregnancy (gestation). Literature review results from 30 journals show that there are research gaps in methodological aspects, where the majority of previous researchers used most quantitative methods, and there were gaps in places and research objects where most of the previous studies generally only focused on PUS aged 15-49 years. (couples of childbearing age) and no one has compared fertility rates between countries.

Conclusion: the factors that influence the level of fertility taken from some literature can be concluded that the level of fertility in a region or region is the result of an individual's decision to limit births. This decision is inseparable from the interaction of the processes of social change, culture, norms, beliefs, economy and growth, urbanization and modernization.

Keywords: Fertility Level, Literature Review 


\section{PENDAHULUAN}

Tiga komponen demografi, kelahiran (fertilitas), kematian (mortalitas) dan migrasi merupakan tri matra kependudukan yang merupakan penentu utama tinggi rendahnya pertumbuhan penduduk. ${ }^{1}$ Jumlah penduduk dunia dari tahun ke tahun cenderung terus mengalami peningkatan termasuk juga di Indonesia, dimana penyebab pertambahan penduduk yang utama adalah karena tingginya tingkat kelahiran. Fertilitas sendiri adalah kemampuan menghasilkan keturunan yang dikaitkan dengan kesuburan wanita atau disebut juga fekunditas. Akan tetapi dalam perkembangan ilmu demografi fertilitas diartikan sebagai hasil reproduksi yang nyata (bayi baru lahir) dari seorang wanita atau sekelompok wanita. ${ }^{2}$ Angka fertilitas di suatu wilayah menunjukkan banyaknya kelahiran (penduduk baru) yang dilahirkan oleh wanita pada usia reproduksi di wilayah tersebut. Hasil Sensus Penduduk tahun 2010 menunjukkan jumlah penduduk Indonesia mencapai 237,6 juta jiwa sehingga menjadikan Indonesia sebagai negara dengan jumlah penduduk terbesar ke empat di dunia setelah Cina, India, dan Amerika Serikat.

Angka fertilitas yang tinggi di suatu negara menimbulkan banyak dampak negatif diantaranya adalah terjadinya ledakan penduduk, terjadinya kekurangan lahan, kekurangan bahan makanan serta akan meningkatkan persaingan hidup. Seiring dengan berkembangnya ilmu pengetahuan, industrialisasi dan pola hidup yang lebih modern, kehadiran anak dianggap krusial terkait dengan biaya (opportunity cost). ${ }^{3}$ Dalam perspektif yang lebih luas, persoalan fertilitas tidak hanya berhubungan dengan jumlah anak sebab aspek yang terkait di dalamnya sangat kompleks dan variatif, misalnya menyangkut perilaku seksual, kehamilan tak dikehendaki, aborsi, PMS, kekerasan seksual, dan lain sebagainya yang tercakup di dalam isu kesehatan reproduksi.

Tingkat fertilitas di suatu wilayah dipengaruhi oleh kondisi sosial dan ekonomi yang saling berkaitan erat. Besar atau kecilnya angka fertilitas berbeda antar wilayah, oleh karena itu pengamatan tentang fertilitas harus didukung oleh ukuran-ukuran lain yang dapat menjelaskan perbedaan fertilitas antar wilayah tersebut. Analisis sosiologis tentang fertilitas mengemukakan bahwa ada 11 variabel antara yang mempengaruhi fertilitas, masing-masing variabel dikelompokkan dalam tiga tahap proses reproduksi. ${ }^{4}$ Variabel antara yang berhubungan dengan tahap hubungan kelamin (intercourse), yaitu umur saat memulai hubungan seks, selibat permanen, lamanya perempuan berstatus kawin, abstinensi sukarela, abstinensi terpaksa, frekuensi hubungan seks. Kedua, variabel antara yang berhubungan dengan tahap konsepsi atau pembuahan (conception), yaitu fekunditas atau infekunditas yang tidak disengaja, fekunditas atau infekunditas yang disengaja (sterilization, subincision, medical treatment), dan pemakaian alat kontrasepsi. Ketiga, variabel antara yang berhubungan tahap kehamilan (gestation) dan successful parturition yaitu, aborsi atau yang tidak disengaja dan aborsi yang disengaja. ${ }^{4}$

Sedangkan faktor-faktor yang mempengaruhi fertilitas adalah sebagai berikut; (a). variabel stratifikasi sosial, yaitu pekerjaan, pendapatan, pendidikan, indeks kekayaan, kekuasaan, serta prestise; (b). variabel struktur keluarga, kemampuan komunikasi yang baik dengan pasangan sangat penting dalam pengendalian fertilitas serta peran dan dominasi salah satu pasangan terhadap preferensi jenis kelamin tertentu; (c). variabel institusi keagamaan dan institusi kesehatan; (d). karakteristik umum organisasi sosialekonomi, masing-masing kelompok sosial ekonomi menunjukkan ciri sendiri. Sebagai contoh pada masyarakat agraris, tingkat fertilitas lebih tinggi daripada masyarakat industri; (e). faktor psikologis, perbedaan fertilitas juga dipengaruhi oleh aspek psikologis antara lain perasaan tidak aman, aspirasi tinggi-rendah, neuroticism, kontrol terhadap impuls, sikap seksual, kebutuhan berprestasi, apatis, fatalism, perasaan tidak mampu; (f). faktor-faktor teknologi, seperti kemajuan dalam efektivitas metode $\mathrm{KB}$, perkembangan industri, dan kondisi lingkungan. Kemajuan dan pengembangan alat KB menjadi lebih efektif sangat relevan dalam pengaturan kelahiran; (g). kematian, penurunan angka kematian menyebabkan turunnya angka fertilitas. ${ }^{5}$

Adapun faktor yang mempengaruhi fertilitas ditinjau dari pendekatan ekonomi 
beberapa ahli menyatakan diantaranya, menurut Leibenstein anak dilihat dari dua aspek yaitu aspek kegunaannya (utility) dan aspek biaya (cost). Kegunaannya adalah memberikan kepuasaan, dapat memberikan balas jasa ekonomi atau membantu dalam kegiatan berproduksi serta merupakan sumber yang dapat menghidupi orang tua di masa depan. ${ }^{6}$ Teori aliran kekayaan oleh John Caldwell menyatakan terdapat hubungan langsung antara struktur keluarga dengan fertilitas. Teori aliran kekayaan (wealth flows theory) tersebut menyatakan bahwa keputusan akan fertilitas dalam masyarakat merupakan respon rasional secara ekonomi pada arus kekayaan suatu keluarga. ${ }^{7}$ Empat aspek modernisasi yang secara empiris diidentifikasi adalah inovasi dalam pelayanan kesehatan publik, inovasi dalam pendidikan formal, urbanisasi, konsumsi barang, pertumbuhan pendapatan per kapita, tenaga kerja perempuan pada sektor modern, kemajuan media massa,

\section{METODE}

Penelitian ini merupakan penelitian studi literatur dengan menelaah 30 jurnal dengan kriteria penelitian kurun waktu 10 tahun terakhir terkait tema fertilitas yang membahas secara spesifik faktor-faktor yang mempengaruhi tingkat fertilitas. Hasil telaah literatur ini bertujuan untuk mengidentifikasi

\section{HASIL}

\section{Konsep Fertilitas}

Pengertian fertilitas dalam demografi lebih dikaitkan dengan banyaknya anak lahir hidup. Istilah fertilitas dapat diartikan juga sebagai kelahiran hidup (live birth), yaitu terlepasnya bayi dari rahim seorang perempuan dengan menunjukkan tanda-tanda kehidupan, misalnya berteriak, bernafas, jantung berdenyut, dan sebagainya. ${ }^{9}$ Ruang lingkup fertilitas hanya mengenai peranan kelahiran pada perubahan penduduk. Hal ini menjadikan fertilitas berkaitan erat dengan bidang demografi dan dipahami sebagai sesuatu yang berbeda dari fekunditas atau kemampuan fisiologis seseorang untuk menghasilkan keturunan yang dikaitkan dengan kesuburan wanita. ${ }^{10}$

Istilah yang dikenal dalam analisis fertilitas menurut Perserikatan Bangsa-Bangsa (PBB) atau United Nations (UN) dan World Health Organization (WHO) antara lain: ${ }^{2}$ program keluarga berencana, kemajuan dalam administrasi pemerintahan, serta perubahan sikap dan kepribadian individu. Kemajuankemajuan yang dicapai dalam modernisasi menyebabkan perubahan pengetahuan, sikap dan perilaku anggota masyarakat dimana adanya perilaku pengaturan kelahiran. ${ }^{8}$

Beranjak dari latar belakang tersebut menarik untuk dikaji lebih mendalam, penelitian ini menyajikan telaah studi literatur mengenai faktor-faktor yang mempengaruhi tingkat fetilitas. Hasil penelitian ini diharapkan sebagai masukan bagi kalangan akademis, dimana hasil penelitian ini dapat memberikan kontribusi bagi pengembangan ilmu pengetahuan serta diharapkan dapat menjadi bahan informasi, referensi dan rujukan baik bagi mahasiswa, peneliti maupun bagi pemerintah dan stockholder dalam pembuatan kebijakan terkait masalah penduduk dan kelahiran.

faktor-faktor penyebab tingkat fertilitas berdasarkan fakta empiris dari penelitianpenelitian terdahulu sehingga membentuk model serta melihat potensi research gap terhadap tema dan topik fertilitas untuk penelitian dimasa yang datang.

Konsep lahir hidup yang didefinisikan WHO yaitu kelahiran hidup sebagai peristiwa kelahiran bayi, tanpa memperhitungkan lamanya berada dalam kandungan, dimana si bayi menunjukkan tanda-tanda kehidupan pada saat dilahirkan; misalnya bernafas, ada denyut jantung, atau denyut tali pusat, atau gerakangerakan otot. Dengan demikian, peristiwa bayi yang lahir dalam keadaan tidak hidup/meninggal (still birth) tidak dimasukkan dalam perhitungan jumlah kelahiran. Untuk bayi yang lahir hidup tetapi kemudian meninggal, beberapa saat setelah lahir atau dikemudian hari, kelahiran hidup ini tetap dimasukkan dalam perhitungan jumlah kelahiran. Tidak termasuk sebagai kelahiran hidup adalah peristiwa keguguran atau bayi yang lahir dalam keadaan meninggal (lahir mati). 
Lahir mati adalah kelahiran seorang bayi dari kandungan yang berumur paling sedikit 28 minggu, tanpa menunjukkan tanda-tanda kehidupan.

Aborsi adalah kematian bayi dalam kandungan dengan umur kehamilan kurang dari 28 minggu. Aborsi dapat terjadi dalam dua

\section{Faktor-faktor yang mempengaruhi Fertilitas}

Berdasarkan variabel-variabel hasil penelitian fakta empiris dengan landasan beberapa teori menunjukkan faktor-faktor yang mempengaruhi macam cara yaitu dengan disengaja (induced abortion) dan tidak disengaja atau secara spontan (spontaneous abortion).

Masa reproduksi adalah masa ketika wanita mampu melahirkan atau disebut juga masa usia subur (15-49 tahun) yaitu sejak mendapat haid pertama (merachea) dan berakhir pada saat berhentihaid (menopause).

tingkat fertilitas maka, dapat diuraikan dengan model sebagai berikut:

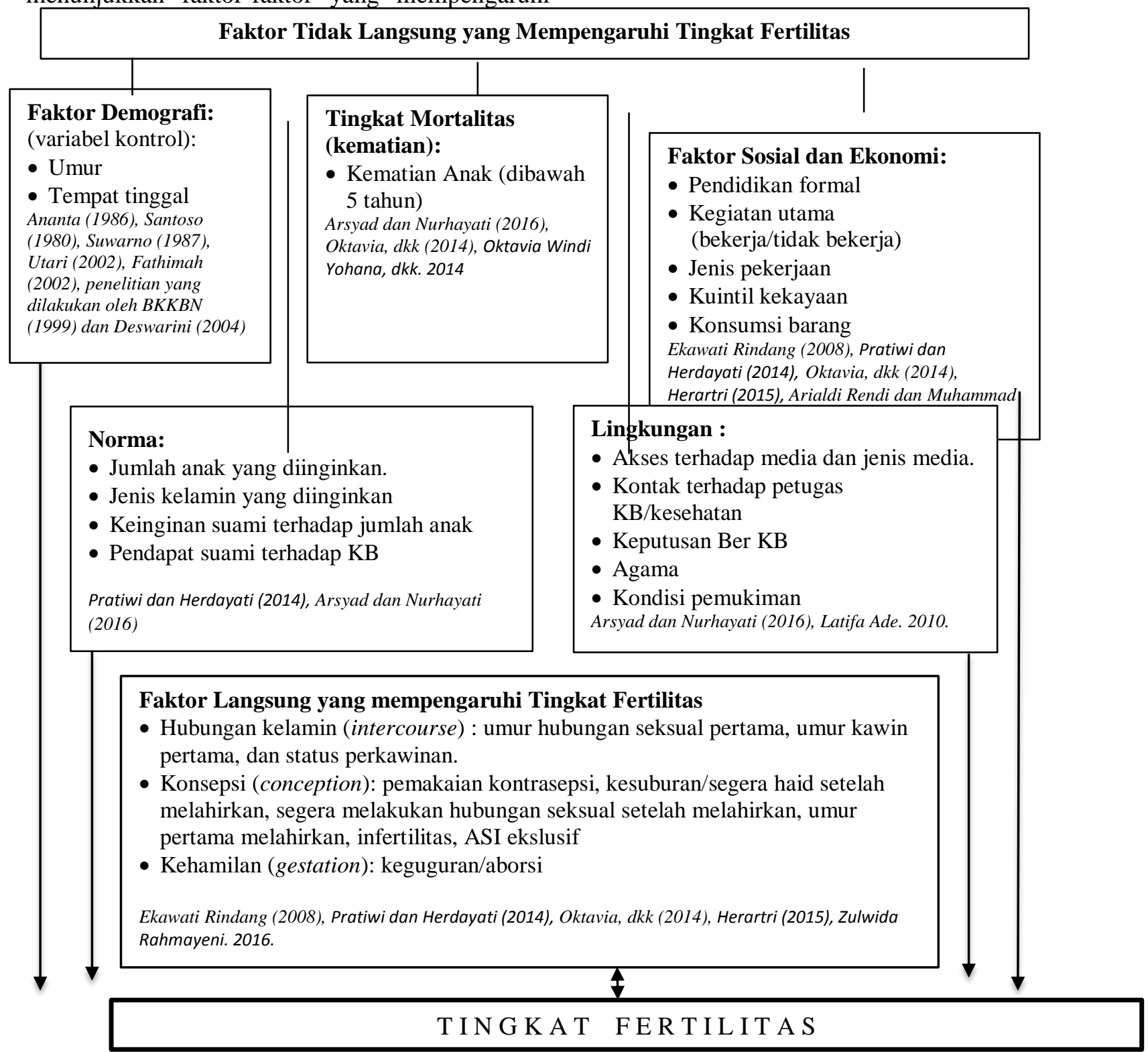

Gambar 1. Model faktor-faktor yang mempengaruhi fertilitas hasil penyederhanaan dan analisis dari beberapa literatur 


\section{Analisis Research Gap Penelitian Terkait Fertilitas}

Berdasarkan penelitian-penelitian terdahulu, dapat diidentifikasi beberapa research gap. Menurut M. Alvesson and Sandberg research gap adalah permasalahan yang belum tuntas diteliti atau belum pernah diteliti oleh penelitian sebelumnya. Research gap dari sebuah penelitian umumnya unik dan menjadikan pembeda antara satu riset dengan riset lainnya. ${ }^{11}$ Berikut research gap yang ditemukan dari telaah jurnal riset terdahulu yang dapat diidentifikasi dalam penelitian ini sebagai berikut :

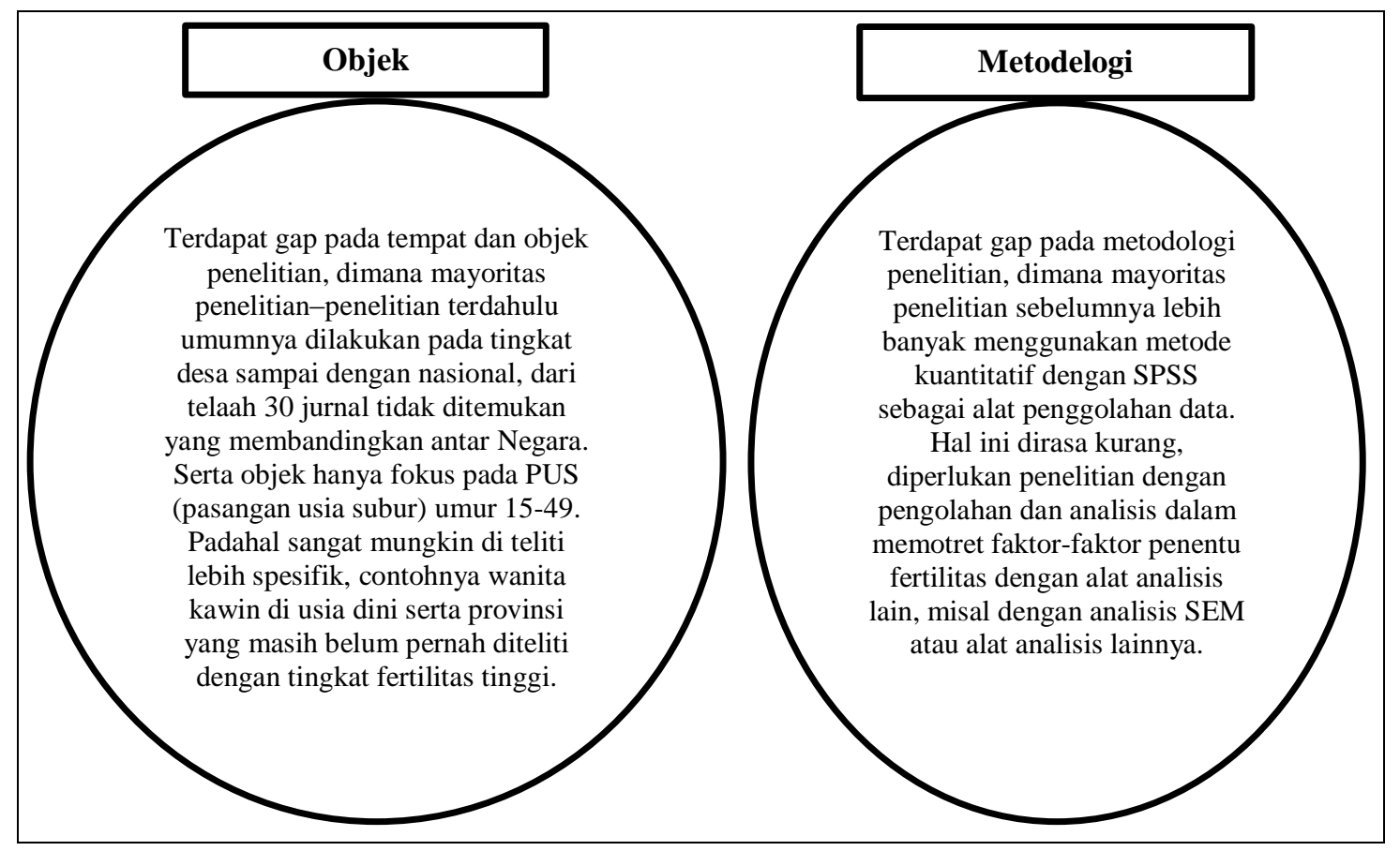

Gambar 2. Research Gap

\section{PEMBAHASAN}

\section{Faktor-faktor yang mempengaruhi Fertilitas Tinjauan Empiris}

Mengacu pada teori Freedman (1961/1962) faktor penentu fertilitas dibagi menjadi faktor secara langsung dan faktor tidak langsung. Adapun faktor tidak langsung adalah: 1). Faktor sosial ekonomi: pendidikan, kegiatan utama (bekerja/tidak bekerja), jenis pekerjaan, kuintil kekayaan sebagai faktor; 2). Faktor Tingkat Mortalitas: Jumlah anak yang meninggal; 3). Faktor norma: jumlah anak yang diinginkan, jenis kelamin anak yang diinginkan, jumlah anak yang diinginkan pasangan, pendapat pasangan terhadap ber-KB, keputusan ber-KB; 4). Faktor lingkungan: terpapar terhadap media tentang $\mathrm{KB}$; serta 5). Faktor demografi sebagai variabel control: umur dan tempat tinggal. Sementara itu, faktor langsung adalah: 1). Faktor yang mempengaruhi terjadinya kehamilan (intercourse): umur pertama kali melakukan hubungan seksual, umur kawin pertama, status perkawinan; 2). Faktor konsepsi (conception): pemakaian kontrasepsi, kesuburan/segera haid setelah melahirkan, segera melakukan hubungan seksual setelah melahirkan, umur pertama melahirkan, infertilitas, ASI ekslusif; 3). Faktor kehamilan (gestation): keguguran/aborsi. ${ }^{5}$

Pendapatan dan jumlah anggota keluarga memiliki pengaruh positif dan signifikan terhadap tingkat kesuburan pada wanita yang menikah. ${ }^{12}$ Selain itu tingkat kelahiran dipengaruhi oleh lama perkawinan, ${ }^{13}$ dan fertilitas juga dipengaruhi oleh tingkat pendidikan, 
struktur umur dan kematian bayi. ${ }^{14}$ Sedangkan keikutsertaan ber KB dipengaruhi oleh umur ibu, tingkat pendidikan dan indeks kesejahteraan, di

Teori menyatakan bahwa semakin tinggi umur ibu, maka semakin banyak jumlah anak yang dilahirkan, karena masa kemungkinan hamil yang makin panjang. ${ }^{16}$ Beberapa hasil penelitian memperlihatkan bahwa rata-rata jumlah anak akan meningkat sejalan dengan meningkatnya umur wanita. Kelompok umur wanita akan mempengaruhi tingkat kesuburannya, dimana jumlah anak yang dimiliki akan membentuk pola huruf $U$ terbalik atau seperti lonceng. ${ }^{16}$ Hal ini tidak sesuai dengan hasil penelitian menunjukkan ada tiga variabel independen yang memiliki pengaruh signifikan, termasuk partisipasi pendidikan tinggi, kepadatan penduduk, dan PDB per kapita dalam jangka panjang, sedangkan angka kematian bayi tidak mempengaruhi perubahan tingkat kesuburan. ${ }^{17}$

Namun satu dari sepuluh remaja wanita umur 15-19 tahun sudah pernah melahirkan dan atau sedang hamil pada saat survey dilakukan; sebanyak 95,2 persen dari remaja yang sudah pernah melahirkan, memiliki satu anak lahir hidup, sisanya sebesar 4,8 persen memiliki dua atau tiga anak lahir hidup; sebesar 11,1 persen dari remaja wanita (15-19 tahun) yang pernah kawin, pertama kali

\section{Researc Gap}

Berdasarkan telaah artikel penelitian terdahulu terkait tema fertilitas dikaji dari aspek tempat penelitian yang dilakukan, dapat dijelaskan bahwa penelitian yang dilakukan memiliki latar belakang yang sama yakni di tingkat nasional (cakupan Indonesia) tempat peneliti melakukan penelitian. ${ }^{22}$ Penelitian dengan latar belakang di tingkat provinsi diantaranya penelitian yang dilakukan di 3 Provinsi yaitu Jawa Barat, Sulawesi Barat dan Kalimantan Selatan, Provinsi Bengkulu dan Provinsi Sumatera Barat. $^{26}$ Selanjutnya penelitian dengan latar belakang penelitian di tingkat Kabupaten atau Kota penelitian yang dilakukan oleh beberapa peneliti sebelumnya sampai mana kesertaan ber KB lebih banyak pada ibu-ibu yang berusia 30-49 tahun, yang berpendidikan lebih tinggi dan indeks kesejahteraan lebih tinggi. ${ }^{15}$

kawin pada saat berumur 10-14 tahun. $^{18}$ Hasil analisis menunjukkan dua puluh empat variabel memiliki hubungan bermakna terhadap ALH (anak lahir hidup), sebelas diantaranya merupakan variabel kuat berpengaruh terhadap ALH. Dengan memperhitungkan variabel kontrol, sebelas variabel tersebut berkontribusi 66 persen terhadap ALH. Kematian anak merupakan variable paling dominan berkontribusi terhadap ALH. ${ }^{19}$

Karakteristik sosial demografi seperti umur, pendidikan, pekerjaan, umur kawin pertama, umur melahirkan anak pertama, dan pemakaian alat kontrasepsi memiliki hubungan yang signifikan dengan fertilitas. ${ }^{20}$ Hasil penelitian menunjukkan pada wanita yang pernah menikah di Provinsi Jawa Barat, mereka yang menikah di usia $\leq 18$ tahun memiliki resiko 2,5 kali lebih tinggi untuk memiliki tingkat fertilitas tinggi dibandingkan yang menikah di usia $\geq 18$ tahun setelah variabel lain dikendalikan. Variabel lain yang turut berperan dalam tingkat fertilitas wanita usia subur yaitu umur, tempat tinggal, tingkat pendidikan istri, status pekerjaan istri, norma tentang besarnya keluarga, dan penggunaan alat kontrasepsi saat ini. ${ }^{21}$

dengan tingkat kecamatan, desa dan kelurahan. ${ }^{34}$

Sedangkan dari aspek objek dan metodelogi penelitian dapat di analisis menggunakan sampel dengan membagi menjadi data kuantitatif sebanyak 1.200 sampel dan data kualitatif dengan melibatkan pengelola program KB melalui proses indept interview. Sampel data kuantitatif yang dipilih adalah wanita usia subur umur 14-19 tahun dan telah memiliki anak. Sedangkan, desain analisis yang digunakan adalah potong lintang, dengan pendekatan kuantitatif menganalisis hasil SDKI tahun 2012 sebagai sumber data dengan sampel sebanyak 45.607 wanita umur 15-49 tahun sebagai unit sampel. Selanjutnya 
penelitian yang dilakukan menggunakan sampel sebesar $10 \%$ dari populasi sebesar 626 migran dan 624 nonmigran (62 migran dan 61 nonmigran) yang diambil secara Proportional Random Sampling. Pengumpulan data primer menggunakan metode wawancara dan sekunder menggunakan pencatatan dokumen yang selanjutnya dianalisis dengan metode deskriptif kualitatif dan kuantitatif. ${ }^{36}$ Penelitian menggunakan desain potong lintang (cross sectional) menggunakan hasil Survei Penduduk Antar Sensus (SUPAS) tahun 2015. Unit analisis pada

\section{KESIMPULAN}

Berdasarkan hasil kajian sebagaimana telah dikemukakan pada hasil dan pembahasan menunjukkan bahwa faktor-faktor yang yang mempengaruhi tingkat fertilitas dari beberapa literature dapat disimpulkan bahwa tinggi rendahnya tingkat fertilitas di suatu daerah atau wilayah adalah hasil dari keputusan individu untuk membatasi kelahiran. Keputusan ini tidak terlepas dari interaksi proses perubahan sosial, budaya, norma, kepercayaan, ekonomi dan pertumbuhannya, urbanisasi dan modernisasi. Dampak proses semua perubahan tersebut, fertilitas dapat langsung dan tidak langsung. Faktor langsung, terdiri: pertama, hubungan seksual (intercourse), kedua, konsepsi (conception), dan ketiga, kehamilan (gestasi).

\section{DAFTAR PUSTAKA}

1. N. Tarmizi, 2012. Tri Matra Kependudukan. Palembang: Unsri Press,.

2. S. M. Adioetomo and O. B. Samosir, 2010. Dasar-Dasar Demografi. Jakarta: Salemba Empat,

3. Becker, 1995. An Economic Analysis of Fertility. Dalam The Essence of B.E.C.K.E.R. Ramon,"

4. K. Davis and J. Blake, 2010. Social Structure and Fertility: An Analytic Framework Author ( $\mathrm{s}$ ): Kingsley Davis and Judith Blake Source: penelitian ini adalah wanita status kawin (anggota rumah tangga wanita yang pada saat pencacahan berstatus kawin) yang berumur 15-49 tahun. Selanjutnya penelitian yang dilakukan peneliti sebelumnya menggunakan pasangan usia subur (PUS) sebagai sampel. Selain itu, metode penelitian dengan pendekatan model, hasil penelitian menunjukkan berdasarkan model pengambilan keputusan, terindikasi bahwa faktor ekonomi berperan penting dalam rasionalitas pengambilan keputusan terkait fertilitas. ${ }^{39}$

Sedangkan untuk faktor tidak langsung: pertama, faktor demografis (variabel kontrol); kedua, faktor sosial dan ekonomi; ketiga, faktor mortalitas (kematian anak); keempat, faktor norma; dan kelima, faktor lingkungan.

Penelitian mendatang diharapkan dapat mengembangkan ruang lingkup penelitian fertilitas tidak hanya di Indonesia tetapi bisa analisis dengan membandingkan tingkat fertilitas dengan Negara lain. Sedangkan untuk objek penelitian tidak hanya pada wanita usia subur (WUS) atau pasangan usia subur (PUS) yang berumur 15 - 49 saja, masih bisa dikembangkan pada ruang lingkup riset wanita usia subur (WUS) atau pasangan usia subur (PUS) yang yang lebih spesifik.

Economic Development and Cultural Change, Published by: The University of Chicago Press Stable U," Development, 4(3):211-235.

5. R. Freedman, 1979. Theories of fertility decline: a reappraisal.," Soc. Forces, vol. 58, no. 1, pp. 1-17, 1979, doi: $10.1093 / \mathrm{sf} / 58.1 .1$.

6. H. Leibenstein,2003.The Economic Theory Of Fertility Decline," $J$. Conflict Resolut., 42(4):1133-1165.

7. H. S. Kaplan and J. Bock, 2001. Fertility Theory: Embodied-capital 
Theory of Life History Evolution," Int. Encycl. Soc. Behav. Sci., 55615568, doi: 10.1016/b0-08-0430767/02225-7.

8. Easterlin, 1983. Modernization and Fertility: A Critical Essay. Determinants of Fertility in Developing Countries," R. B. and R. Lee., Ed.

9. M. B. Raharja and D. Wahyuni, "Fertilitas Remaja di Indonesia," Jakarta, 2013.

10. S. Yuniarti, H. Sukandar, and $\mathrm{H}$. Susiarno, 2011. Analisis faktor yang berhubungan dengan fertilitas, 38, 111.

11. M. Alvesson and Sandberg, 2011. Generating Research Questions Through Problematization," Acad. Manag. Rev., 36 (2): 247.

12. S. Normalasari, I. Gani, and S. Amalia, 2018. Faktor-faktor sosial ekonomi pada wanita yang menikah dini dalam mempengaruhi fertilitas, 14(1): 29-35.

13. R. Guntara and S. Yulianto, 2014. Analisis Faktor-Faktor yang Mempengaruhi Tingkat Kelahiran di Kabupaten Brebes dengan Pendekatan Regresi Logistik Biner, 264-272,

14. W. Y. Oktavia, T. S. Putro, and L. Sari, 2008. "Pengaruh tingkat pendidikan, struktur umur dan kematian bayi terhadap fertilitas di Kota Pekanbaru, 1(2): 1-15.

15. R. Ekawati, 2014. Faktor Karakteristik Keluarga , Tingkat Fertilitas dan Pemakaian Kontrasepsi, 10 (2):135151.

16. S. Adioetomo, 1980. Pola Fertilitas di Indonesia: Analisa Secara Umum. Jakarta: BPS dan Lembaga Demografi Fakultas Ekonomi Universitas

17. P. K. Aprila Severus, 2019. Pengaruh Pendidikan Tinggi, Kepadatan Penduduk, Mortalitas Bayi, dan PDB Per-Kapita Terhadap Tingkat Fertilitas di Indonesia," Edunomic J. Pendidik. Ekon., 7(2): 85, doi: 10.33603/ejpe.v7i2.2307.

18. M. B. Raharja, 2014. Fertilitas Remaja di Indonesia," Kesmas Natl. Public
Heal. J., 9 (1): 6, doi: 10.21109/kesmas.v9i1.449.

19. S. S. Arsyad and S. Nurhayati, 2016. Determinan Fertilitas Di Indonesia (Determinant Of Fertility In Indonesia), 11(1): 1-14,

20. R. Herartri and M. Dawam, "Fertilitas Wanita Migran Dan Non Migran Di Indonesia Analisis Data Supas 2015," pp. 1-52, 2016.

21. Y. P. Pratiwi and M. Herdayati, "2014. Pengaruh Umur Kawin Pertama Terhadap Tingkat Fertilitas Wanita Usia Subur Di Provinsi Jawa Barat Tahun 2012 (Analisis Lanjut Survei Demografi Kesehatan Indonesia 2012).

22. R. Pebrianti and Rahmadewi, 2014. Dampak Usia Kawin Pertama ( UKP ) Terhadap Fertilitas.

23. M. Dawam and S. S. Arsyad, "Isu Terkait Dengan Kawin Dan Melahirkan," 2016.

24. F. Hadiyanto, 2017. Faktor-Faktor Yang Mempengaruhi Fertilitas Di Jawa Barat, 22(1): 34-42,

25. H. Sunaryanto, 2012. Analisis Fertilitas Penduduk: Provinsi Bengkulu ( The Analysis Of Population Fertility: Bengkulu Province ), 7 (1):19-38.

26. D. Larasati, Idris, and A. Ali, 2018. Analisis Pengaruh Faktor Sosial Ekonomi Rumah Tangga Terhadap Fertilitas Di Sumatera Barat,1: 648658.

27. Refrihardi and D. Z. Putri, 2019. Faktor-Faktor Yang Mempengaruhi Fertilitas Pada Pasangan Yang Menikah Diusia Dini Di Kabupaten Sijunjung," J. Kaji. Ekon. dan Pembang., 1:705-720,

28. Y. Pungan, 2016. Analisis Fertilitas Pada Wanita Bekerja Di Kota Palangka Raya," J. Komun. Bisnis dan Manaj., 3 (6).

29. M. A. Wirda, A. Irfany, D. Septiyani, and D. T. S, 2018. Analisis Faktor yang Mempengaruhi Tingkat Fertilitas Di Desa Laut Dendang Kecamatan Percut Sei Tuan Kabupaten Deli 
Serdang," 07(02):133-145.

30. G. P. Aliviona, 2014. Analisis Faktor - Faktor Yang Mempengaruhi Tingginya Fertilitas Di Kecamatan Jabon Kabupaten Sidoarjo, 68-74.

31. I. A. Sulistyaningsih, 2012. Faktor Faktor Yang Mempengaruhi Tingginya Fertilitas Di Kecamatan Tambaksari Kota Surabaya.

32. Z. Rahmayeni, 2016. Faktor-Faktor Yang Mempengaruhi Fertilitas Pasangan Usia Subur Peserta KB Di Kelurahan Aur Kuning Kecamatan Aur Birugo Tigo Baleh, 23 (2):30-38.

33. L. Sinaga and P. H. Prihanto, 2017.Faktor-faktor yang mempengaruhi tingkat fertilitas di perdesaan (Studi pada Desa Pelayangan Kecamatan Muara Tembesi Kabupaten Batanghari), 12 (1):1-48.

34. S. Yuniarti and T. Setiowati, "Analisis Faktor yang Berhubungan dengan Tingkat Fertilitas pada Ibu Pasangan Usia Subur ( PUS ) di Wilayah Kerja PUSKESMAS Melong Asih Kota Cimahi," 2015.
35. Setiasih Karunia, N. Endah, S. Sugoto, S. Wahyuningsih, and I. Setyaningrum, 2013. Faktor yang mempengaruhi wanita melahirkan umur 15-19 tahun.

36. M. A. S. Haribaik, I. bagus M. Astawa, and Sutarjo, 2017. Studi Komparatif Tentang Fertilitas Migran Dan Nonmigran Di Kota Singaraja," J. Pendidik. Geogr., 5(3).

37. Rahmadewi and Leli Asih, 2011. Tingkat Fertilitas di Provinsi Nusa Tenggara Timur dan Yogyakarta," Kesmas, J. Kesehat. Masy. Nas. 6(1):117-125.

38. R. Arialdi and S. Muhammad, 2016. Pengaruh Urbanisasi, Pendidikan Dan Pendapatan Terhadap Tingkat Fertilitas Di Lima Kota Provinsi Aceh, 1: 208-216.

39. A. Latifa, 2010. Aplikasi Model Pengambilan Keputusan Dalam Perilaku Fertilitas, 5(1): 55-73.

40. G. S. Becker and R. J. Barro, 2013. A Reformulation of the Economic Theory of Fertility, 103( 1):1-25. 